\title{
Human T Lymphotropic Virus Type I protein Tax reduces histone levels
} James M Bogenberger and Paul J Laybourn*

\author{
Address: Department of Biochemistry and Molecular Biology, Colorado State University, Fort Collins, Colorado, USA \\ Email: James M Bogenberger - jimbog@simla.colostate.edu; Paul J Laybourn* - paul.laybourn@colostate.edu \\ * Corresponding author
}

Published: 31 January 2008

Retrovirology 2008, 5:9 doi:10.1186/1742-4690-5-9

This article is available from: http://www.retrovirology.com/content/5/I/9

(c) 2008 Bogenberger and Laybourn; licensee BioMed Central Ltd.

This is an Open Access article distributed under the terms of the Creative Commons Attribution License (http://creativecommons.org/licenses/by/2.0), which permits unrestricted use, distribution, and reproduction in any medium, provided the original work is properly cited.
Accepted: 31 January 2008
Received: I November 2007

\begin{abstract}
Background: Human T-Lymphotropic Virus Type-I (HTLV-I) is an oncogenic retrovirus that causes adult T-cell leukemia/lymphoma (ATLL). The virally encoded Tax protein is thought to be necessary and sufficient for T-cell leukemogenesis. Tax promotes inappropriate cellular proliferation, represses multiple DNA repair mechanisms, deregulates cell cycle checkpoints, and induces genomic instability. All of these Tax effects are thought to cooperate in the development of ATLL.
\end{abstract}

Results: In this study, we demonstrate that histone protein levels are reduced in HTLV-I infected T-cell lines (HuTI02, SLB-I and C8I) relative to uninfected T-cell lines (CEM, Jurkat and Molt4), while the relative amount of DNA per haploid complement is unaffected. In addition, we show that replication-dependent core and linker histone transcript levels are reduced in HTLV-I infected Tcell lines. Furthermore, we show that Tax expression in Jurkat cells is sufficient for reduction of replication-dependent histone transcript levels.

Conclusion: These results demonstrate that Tax disrupts the proper regulation of replicationdependent histone gene expression. Further, our findings suggest that HTLV-I infection uncouples replication-dependent histone gene expression and DNA replication, allowing the depletion of histone proteins with cell division. Histone proteins are involved in the regulation of all metabolic processes involving DNA including transcription, replication, repair and recombination. This study provides a previously unidentified mechanism by which Tax may directly induce chromosomal instability and deregulate gene expression through reduced histone levels.

\section{Background}

Human T-lymphotropic virus type 1 (HTLV-1) is a complex retrovirus originally isolated in 1980 from a patient with cutaneous T-cell lymphoma [1]. After the identification of HTLV-1 as the first human retrovirus, it was demonstrated to be associated with a malignancy of $\mathrm{T}$ lymphocytes known as adult T-cell leukemia/lymphoma (ATLL) [2-6]. ATLL is now known to be a direct result of HTLV-1 infection [7]. HTLV-1 is also associated with non- malignant, lymphocyte-mediated inflammatory diseases, including the neurodegenerative disease tropical spastic paraparesis/HTLV-I associated myelopathy (TSP/HAM) [8-10].

The pathogenesis of HTLV-1 differs from that of other known retroviruses. Unlike the acutely transforming retroviruses, HTLV-1 does not encode an oncogene transduced from a host genome [11]. Additionally, HTLV-1 can 
induce ATLL independently of the cis-acting effects of proviral integration, distinguishing it from the slowly transforming, cis-acting retroviruses [12]. Like other retroviruses, the HTLV-1 genome consists of two long-terminal repeats (LTRs) flanking the common retroviral genes gag, pro, pol, and env [11]. HTLV-1 contains an additional genomic segment between the env gene and the 3' LTR, called the $\mathrm{pX}$ region [13]. The $\mathrm{pX}$ region contains four partially overlapping open reading frames (ORFs), encoding several nonstructural or accessory viral gene products required for viral replication and infectivity [1419]. ORF IV encodes the viral transcription factor Tax [13]. Tax is essential for replication of the HTLV-1 genome and is required for HTLV-1 pathogenesis. Although there is no known cellular homolog, Tax is considered to be an oncoprotein. Tax has been shown to be necessary and sufficient to transform primary T-cells and form tumors in transgenic mice [6,20-24].

The oncogenic capacity of Tax resides in its ability to induce inappropriate cell proliferation, inhibit DNA repair pathways, deregulate cell cycle checkpoint controls, and induce genomic instability. These effects of Tax on cellular homeostasis are mediated both by Tax deregulation of cellular gene expression and by direct Tax interactions with multiple regulators of cellular homeostasis [2527]. It is thought that all of these effects of Tax function to promote viral replication [28]. HTLV-1 infected cells produce virtually no cell-free infectious virus particles. Rather, infection appears to be mediated by cell-to-cell contact [29-31]. The ability of Tax to drive cell cycle progression and inactivate cell cycle checkpoints promotes replication of the proviral genome, but consequently results in an increased frequency of neoplasia in the host cell.

In addition to Tax, the HTLV-1 genome encodes five other accessory proteins, p12 1 p30 II, p13 II, HBZ and Rex. Of these proteins, $\mathrm{p} 12^{\mathrm{I}}, \mathrm{p} 30^{\mathrm{II}}$ and $\mathrm{p} 13^{\mathrm{II}}$ are not essential for viral replication in vitro and Rex is not required for T-cell immortalization [32]. However, experiments in animal models using infectious viral clones suggest that these other accessory proteins are important for productive infection in vivo [33-35]. Accessory protein $\mathrm{p} 12^{\mathrm{I}}$ localizes to the endoplasmic reticulum and Golgi and appears to promote cell survival and proliferation through increased cytoplasmic $\mathrm{Ca}^{++}$levels [36]. This protein may also participate in immune response evasion through reduction of MHC expression [37]. Similarly, p30 II may function to promote cell proliferation at the same time as viral latency through effects on CBP/p300 function, as well as, Tax and Rex mRNA translation [38-40]. Accessory protein p13 II localizes to the mitochondrial inner membrane and affects $\mathrm{K}^{+}$permeability and $\mathrm{Ca}^{++}$uptake suggesting a function through $\mathrm{Ca}^{++}$signaling, as well [41]. The HBZ open reading frame is transcribed from the minus DNA strand using a promoter in the 3 -LTR and is thought to produce both a protein and an RNA product [42-44]. HBZ RNA appears to promote $\mathrm{T}$-cell proliferation while the protein product suppresses viral transcriptional activation by Tax $[45,46]$. Rex function is important for viral replication, as it drives the transition to production of full-length genomic RNA $[47,48]$. Rex is thought to recognize a sequence in the viral RNA (Rex response element; RxRE), repress splicing, and promote nuclear export [49]. Rex has also been shown to be dispensable for virion production in vitro, but to be essential in vivo [50].

Evidence from clinical studies suggests that fewer than 5\% of infected individuals develop ATLL and that manifestation of ATLL occurs after a long latent period between 2060 years [51]. These observations suggest that secondary events are required in the progression from HTLV-1 infection to T-cell transformation and the development of ATLL. Multi-step oncogenesis is thought to be driven by reduced DNA repair capacity and/or genomic instability [52].

Both ATLL cells and those immortalized by HTLV-1 infection and Tax expression in culture exhibit a broad spectrum of chromosomal abnormalities, including deletions, duplications, translocations and anneuploidy [53,54]. Tax expression and DNA damage have been correlated in studies demonstrating that Tax expression results in the formation of micronuclei $[55,56]$. Tax expression has been shown to induce gene amplification, as well [57]. Tax expression has been observed to cause an uncoupling of DNA synthesis from cell division and result in the formation of multinucleated giant cells exhibiting decondensed, highly convoluted and polylobulated nuclei [58]. This phenotype is similar to that of the large lymphocytes with cleaved or cerebriform nuclei observed at higher frequencies in HTLV-1 positive individuals [59]. The clastogenic effects of Tax have been correlated with unstabilized double strand DNA breaks [60]. Currently, there is no clear mechanism for how chromosomal abnormalities arise in HTLV-1 infected cells and there is no evidence linking a specific chromosomal abnormality to the development of ATLL.

Histones are critical components of chromatin and are required for the proper packaging of genomic DNA within the eukaryotic nucleus. The core histones assemble with DNA into nucleosome core particles, the fundamental units of chromatin. Arrays of nucleosome core particles constitute a chromatin fiber, the primary level of chromatin structure. The chromatin fiber is further compacted through the formation of additional levels of higher order chromatin structure. Linker histones are thought to modulate nucleosome dynamics and higher-order chromatin 
structure formation. Ultimately, the chromatin fiber is compacted by non-histone proteins forming metaphase chromatids or chromosomes, the most compacted state of genomic DNA. Histones and chromatin structure play a central role in the regulation of all DNA metabolic processes, including transcription, repair, replication and recombination [61].

In the present study we demonstrate that HTLV-1 infected T-cell lines exhibit a reduction of replication-dependent histone protein and transcript levels relative to uninfected T-cell lines. However, we detect no concomitant decrease in genomic DNA. Further, we show that Tax expression in an uninfected T-cell line is sufficient to repress replicationdependent histone transcript levels. These results provide a previously unidentified mechanism through which Tax may deregulate gene expression. Additionally, these results provide a mechanism by which Tax may directly induce genomic instability.

\section{Results}

Phenotypically, ATLL cells exhibit enlarged, polylobulated nuclei as well as micronuclei [56,59]. In addition, the viral transcription factor Tax is thought to deregulate the expression of hundreds of cellular genes [62-65]. We were interested in investigating the possibility that these attributes result, in part, from defects in forming proper chromatin structure. Since histones are critical to the formation of chromatin structure, we hypothesized that HTLV-1 infection and Tax perturb normal histone gene expression.

\section{Histone $\mathrm{H3}$ and $\mathrm{HI}$ levels are reduced in HTLV-I infected T-cell lines}

To quantify histone protein levels we sought to measure histone protein and DNA content simultaneously using a flow cytometry based assay. This assay has several advantages over other methods of measuring cellular histone protein levels. In normal cells, histone protein levels are dependent on cellular DNA content. This fact has important consequences for the measurement of histone protein levels in different cell lines. Differences in the amount of DNA per haploid complement will result in concomitant differences in histone protein levels during interphase. Additionally, as cells replicate genomic DNA during S-phase, histone protein levels will increase along with the DNA content. Thus, simultaneous quantification of histone protein and DNA content allowed us to normalize histone protein levels to DNA content. The ability to detect the slight increases in both histone protein and DNA content as cells progress through S-phase attests to the quantitative sensitivity of our assay.

Histone H3 and DNA content were measured simultaneously by flow cytometry. The antibody used (see Materials and Methods) is directed against the $\mathrm{H} 3$ carboxyl-terminus and recognizes modified forms of $\mathrm{H} 3$ and $\mathrm{H} 3$ variants. In addition, $\mathrm{H} 3$ forms the core heterotetramer of nucleosomes, along with $\mathrm{H} 4$. It is important to note that somatic cells, regardless of cell cycle phase, contain no significant histone pools and levels of all four core histones and total linker histone are finely balanced. It has been estimated that even during $S$ phase, the soluble histone pool represents about $0.1 \%$ of the total histone in human cells $[66,67]$. Therefore, the levels of $\mathrm{H} 3$ measured using this antibody are indicative of the nucleosomal levels on the chromosomes. During flow cytometry, the level of anti-H3 antibody bound per cell was measured using an Alexa 488-conjugated secondary antibody. Cells were also stained with propidium iodide (PI) to determine genomic DNA content. Unstained cells, as well as cells treated with primary antibody only, secondary antibody only, PI only, or primary and secondary antibody only were included as controls in every experimental analysis to determine background fluoresence and in instrument calibration.

Mean histone H3 signal intensity was traced from G1 through G2/M and plotted against mean genomic DNA content (Figure 1A). This was accomplished by defining a narrow window on each DNA histogram so that the histone $\mathrm{H} 3$ levels for the corresponding cell population defined by the window could be determined at a particular DNA content level. Our results show that upon initiation of DNA replication at the onset of $S$ phase, cells exhibit a near linear increase in both DNA and histone H3 content. As cells approach G2/M histone H3 immunofluoresence was observed to plateau in all T-cell lines examined (both infected and uninfected), while PI fluorescence (DNA content) continued to increase in a near linear fashion. The plateau in H3 immunofluoresence observed may be explained by a decrease in $\mathrm{H} 3$ antibody epitope accessibility during chromosome condensation. Nevertheless, the simultaneous measurement of histone levels and DNA content using flow cytometry is clearly sensitive and quantitative enough to accurately measure the slight increases in both DNA and histone associated with genome replication as cells progress through $\mathrm{S}$ phase of the cell cycle. To display the histone H3 levels measured for each of the cell lines examined, the average histone H3:DNA ratios corresponding to G1, Mid-S and G2/M cell populations were calculated for each cell line and expressed relative to Jurkat (Figure 1B).

To summarize our results, histone H3 levels are not significantly different between each of the three uninfected Tcell lines, Jurkat, CEM and Molt4. In clear contrast, H3 levels are reduced 20 to $40 \%$ in the HTLV-1 infected T-cell lines, SLB-1, HuT102 and C81, relative to Jurkat cells. The p-values associated with the measurement of histone 
A

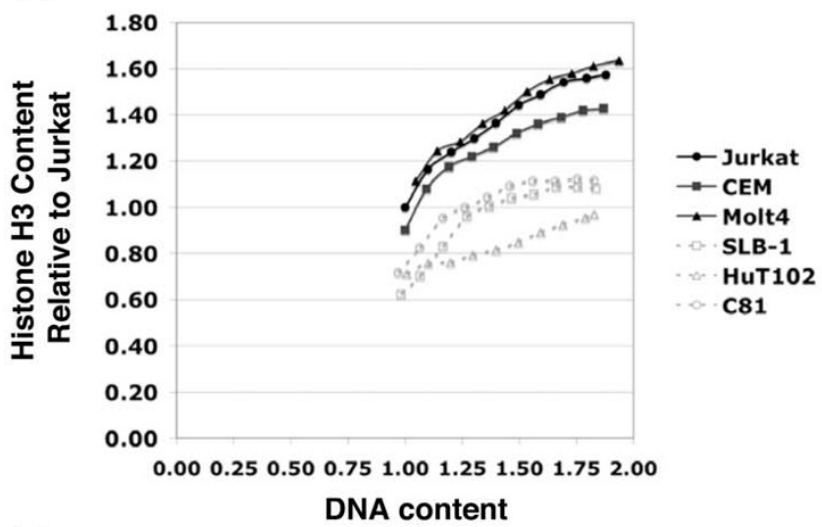

B

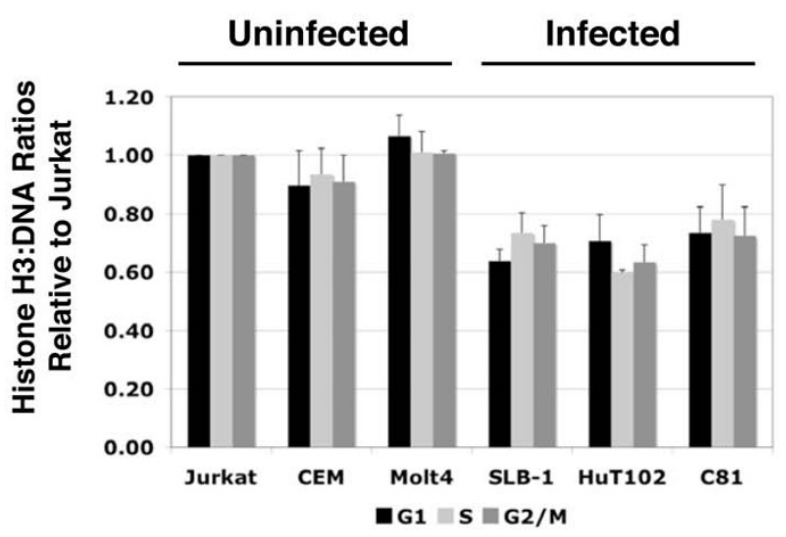

C

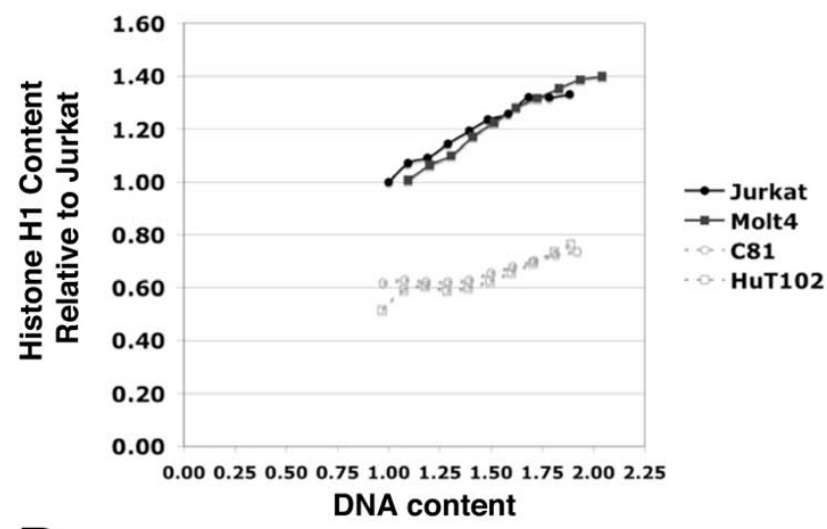

D

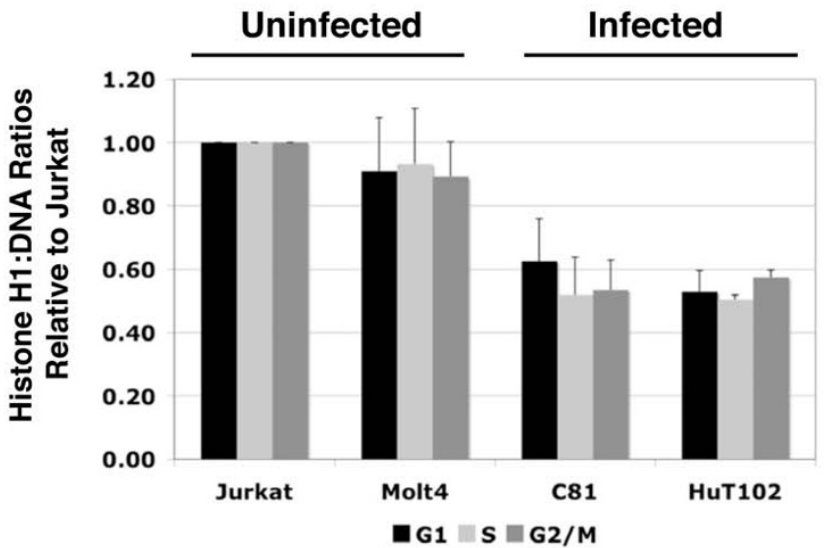

Figure I

Histone $\mathrm{H} 3$ and $\mathrm{HI}$ levels are reduced relative to genomic DNA content. Histone $\mathrm{H} 3$ and genomic DNA content were measured simultaneously in uninfected T-cell lines (CEM, Jurkat and Molt4) and HTLV-I infected T-cell lines (SLB-I, HuTIO2 and C8I) using flow cytometry. H3 levels were measured using a primary antibody directed against the C-terminal domain and an Alexa-488 labeled secondary antibody. DNA content was measured using propidium iodide. (A) Mean histone H3 immunofluorescent intensity was traced from $\mathrm{Gl}$ through $\mathrm{G} 2 / \mathrm{M}$ by defining a narrow window on the DNA histogram and plotted against the genomic DNA content for the corresponding cell population defined by the window. (B) The average histone H3:DNA ratios of three experiments during GI, Mid-S and G2/M are shown for HTLV-I infected and uninfected T-cell lines (see Table I for p-values) (C) Histone $\mathrm{HI}$ and genomic DNA content were measured simultaneously in uninfected T-cell lines (Jurkat and Molt4) and in HTLV-I infected T-cell lines (C8I and HuTI02) using flow cytometry. HI levels were measured using a primary antibody directed against the C-terminal domain and an Alexa-488 labeled secondary antibody. DNA content was measured using propidium iodide. Mean histone $\mathrm{HI}$ immunofluorescent intensity was traced from $\mathrm{GI}$ through $\mathrm{G} 2 / \mathrm{M}$ by defining a narrow window on the DNA histogram and plotted against the genomic DNA content for the corresponding cell population defined by the window. (D) The average histone HI:DNA ratios during GI, Mid-S and G2/M are shown for HTLV$\mathrm{I}$ infected and uninfected T-cell lines (see Table 2 for $\mathrm{p}$-values).

H3:DNA ratios are shown in Table 1 . The reduction in histone $\mathrm{H} 3$ observed is consistent throughout the cell cycle.

Histone $\mathrm{H} 1$ protein levels were determined using the same flow cytometry-based assay. Histone H1 levels are plotted against genomic DNA content (Figure 1C) and histone $\mathrm{H1}$ :DNA ratios are determined (Figure 1D). Histone $\mathrm{H} 1$ protein levels are not significantly different in the two uninfected T-cell lines examined, Jurkat and Molt4.
However, histone $\mathrm{H} 1$ protein levels are reduced by $40 \%$ in the two infected T-cell lines examined, C81 and HuT102 as compared to the uninfected T-cell lines, Molt4 and Jurkat. The p-values associated with the measurement of histone H1:DNA ratios are shown in Table 2. The reduction of histone $\mathrm{H} 1$ is also consistent throughout the cell cycle. 
Table I: P-values for data in Figure IB. Note: Jurkat values have been set to I.0.

\begin{tabular}{lccl}
\hline H3:DNA & GI & Mid-S & G2/M \\
\hline CEM & $1.7 \times 10^{-1}$ & $2.2 \times 10^{-1}$ & $1.5 \times 10^{-1}$ \\
Molt4 & $1.6 \times 10^{-1}$ & $4.2 \times 10^{-1}$ & $2.6 \times 10^{-1}$ \\
SLB-I & $3.0 \times 10^{-3}$ & $1.5 \times 10^{-2}$ & $1.1 \times 10^{-2}$ \\
HuTI02 & $2.2 \times 10^{-2}$ & $9.4 \times 10^{-5}$ & $6.4 \times 10^{-3}$ \\
C8 I & $2.6 \times 10^{-2}$ & $6.0 \times 10^{-2}$ & $3.3 \times 10^{-2}$ \\
\end{tabular}

Having unequivocally determined that histone protein levels are reduced in HTLV-1 infected T-cell lines, we proceeded to determine if this was a result of reduced histone message levels.

\section{Replication-dependent histone transcript levels are reduced in $H T L V$ - $I$ infected $T$-cell lines}

The replication-dependent histones are expressed from multiple gene copies. While their amino acid sequences are highly conserved they are divergent enough in their DNA sequences as to require a separate primer set for the measurement of transcript from each of the gene copies by real-time PCR. Therefore, Northern blot analysis was employed allowing the measurement of total transcript levels for each replication-dependent histone type. Histone transcript levels in each cell line were normalized against EF1 $\alpha$. Northern blot analyses revealed a reduction of histone transcripts from all of the replication-dependent histone genes (Figure 2A). Quantification of the Northern blot results revealed a reduction in core and linker histone transcript levels ranging from two to fivefold, depending on the histone, in HTLV-1 infected T-cell lines (HUT102, SLB-1 and C81) as compared to Jurkat Tcells (Figure 2B). On average, histone transcripts are reduced by $66 \%, 61 \%$ and $50 \%$ in SLB- 1 , HuT102 and C81 cells respectively. Histone transcript levels in the other uninfected T-cell lines examined, Molt4 and CEM, were either not significantly different from or slightly higher than Jurkat. These results indicate that HTLV-1 infection is reducing histone protein levels through an effect on histone transcript levels.

Table 2: P-values for data in Figure ID. Note: Jurkat values have been set to I.0.

\begin{tabular}{lccl}
\hline HI:DNA & GI & Mid-S & G2/M \\
\hline Molt4 & $3.5 \times 10^{-1}$ & $3.9 \times 10^{-1}$ & $2.5 \times 10^{-1}$ \\
C8 I & $1.1 \times 10^{-1}$ & $8.0 \times 10^{-2}$ & $6.0 \times 10^{-2}$ \\
HuTI02 & $5.0 \times 10^{-2}$ & $1.0 \times 10^{-2}$ & $2.0 \times 10^{-2}$
\end{tabular}

\section{All linker histone isoform transcript levels are reduced in HTLV-I infected T-cell lines}

We used reverse-transcription and real-time PCR to determine the transcript levels of each of the somatic linker histone isoforms. Real-time PCR quantification of linker histone cDNAs generated from an uninfected T-cell line (Jurkat) and from an HTLV-1 infected T-cell line (SLB-1) reveals a significant reduction of somatic linker histone transcripts in the HTLV-1 infected T-cell line when compared to the uninfected T-cell line (Figure 2C). H1 $1^{\mathrm{S}}-1$, $\mathrm{H}_{1} \mathrm{~S}_{-} 2, \mathrm{H}_{1} \mathrm{~s}_{-} 3$, and $\mathrm{H}_{1} \mathrm{~S}_{-} 4$ transcripts are $6,14,9$ and 4 -fold lower in SLB-1 cells, respectively, relative to Jurkat T-cells. These results indicate that HTLV-1 infection is reducing histone protein levels through an effect on histone transcript levels.

\section{Tax expression alone reduces histone transcript levels in an uninfected $T$-cell line}

The HTLV-1 provirus encodes several viral proteins, but only the Tax protein is known to be oncogenic. To determine if Tax alone is sufficient to repress histone gene expression, we transiently transfected an uninfected T-cell line (Jurkat) with a Tax expression vector (pSG-Tax) or empty vector (pUC-19). Both sets of cells were cotransfected with a vector encoding a surface molecule (truncated mouse MHC Class I) to allow selection of transfectants by their retention on magnetic beads conjugated to antibody recognizing this unique surface marker. Real-time PCR was used to evaluate all of the somatic linker histone mRNAs and representative family members of the core histone genes in Tax expressing and pUC-19 transfected Jurkat cells. Tax expression was verified by both western blot and real-time PCR (not shown).

Both core and linker histone mRNAs were reduced in Tax expressing Jurkat cells as compared to pUC-19 transfected Jurkat cells (Figure 3A). Core and linker histone mRNA levels are reduced in the range of three- to five-fold, similar to the reduction observed in HTLV-1 infected T-cell lines. Replication-dependent histones are only transcribed in S phase of the cell cycle. To eliminate the possibility that Tax expressing cells reduce replicationdependent histone transcript levels by reducing the proportion of cells in S phase, we determined cell cycle distributions of pSG-Tax and pUC-19 transfected Jurkat cells. pSG-Tax and pUC-19 transfected Jurkat cells used for RNA extraction were subjected to cell cycle analysis. The percentage of cells in S phase of Tax expressing Jurkat cell populations was $31 \%$, while that of pUC-19 transfected Jurkat cells was $36 \%$ (Figure $3 \mathrm{~B}$ ). The reduction of histone mRNAs observed in Tax expressing Jurkat cells due to the lower proportion of cells in S phase is no more than 14\% (31/36). Therefore, Tax effects on cell cycle distribution do not account for the remaining 52 to $66 \%$ reduction in 
A

HTLV-1

Uninfected Infected

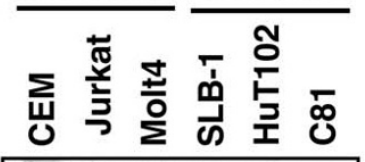

-

S- H2A

O- H2B

He- H3

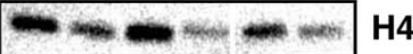

-

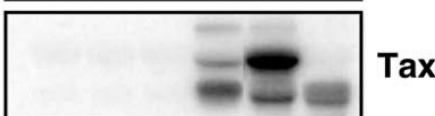

B

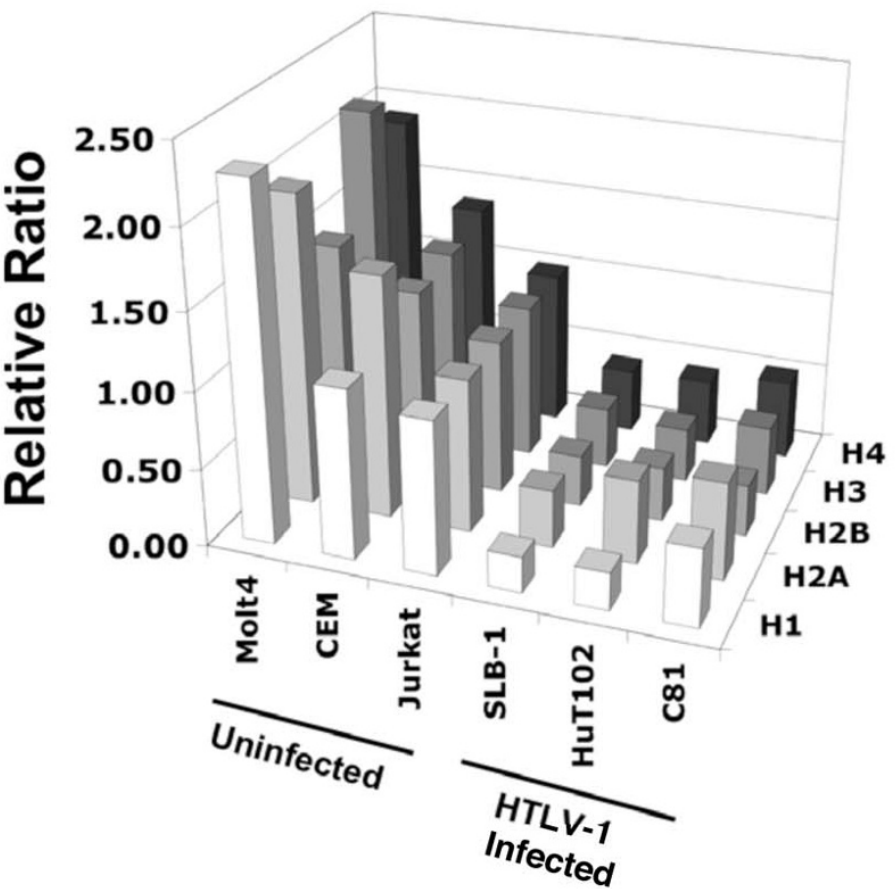

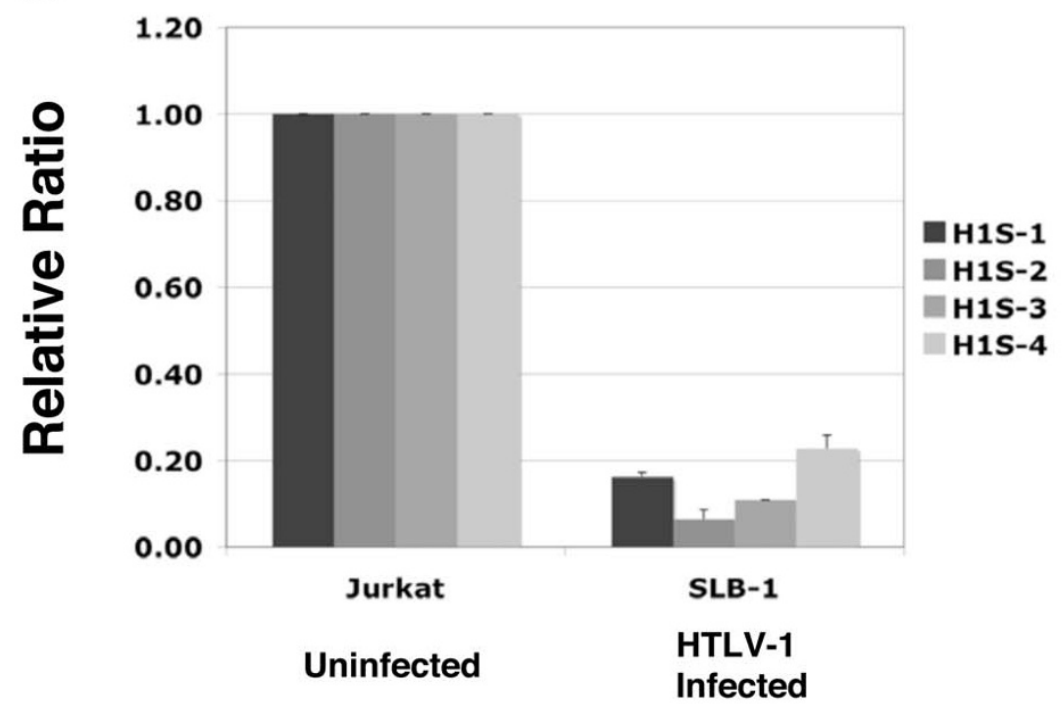

Figure 2

Replication-dependent core and linker histone transcripts are reduced in HTLV-I infected T-cell lines. (A) Core and linker histone transcript levels were measured in uninfected T-cell lines (CEM, Jurkat and Molt4) and HTLV-I infected T-cell lines (SLB-I, HuTIO2 and C8I) by northern blotting. (B) Graphical representation of northern blot quantification. Histone transcript signals were normalized to EFI $\alpha$ transcript signals. Values for all T-cell lines are expressed relative to Jurkat cells. P-values associated with northern blot measurements of total histone transcripts for each cell line were: CEM-2.3 $\times 10^{-3}$, Molt4 - I.I × 10-4, SLB-I $-5.8 \times 10^{-12}$, HuTI $02-2.9 \times 10^{-8}, \mathrm{C} 8 \mathrm{I}-2.8 \times 10^{-6}$ (C) Linker histone isoform transcripts are reduced in HTLV-I infected T-cell lines. Somatic linker histone isoform transcript levels were measured in an uninfected T-cell line (Jurkat) and an HTLV-I infected T-cell line (SLB-I), using reverse-transcription and real-time PCR. Linker histone transcript levels were normalized to EFI $\alpha$ transcript levels and values were expressed relative to transcript levels in Jurkat cells [110]. 
A
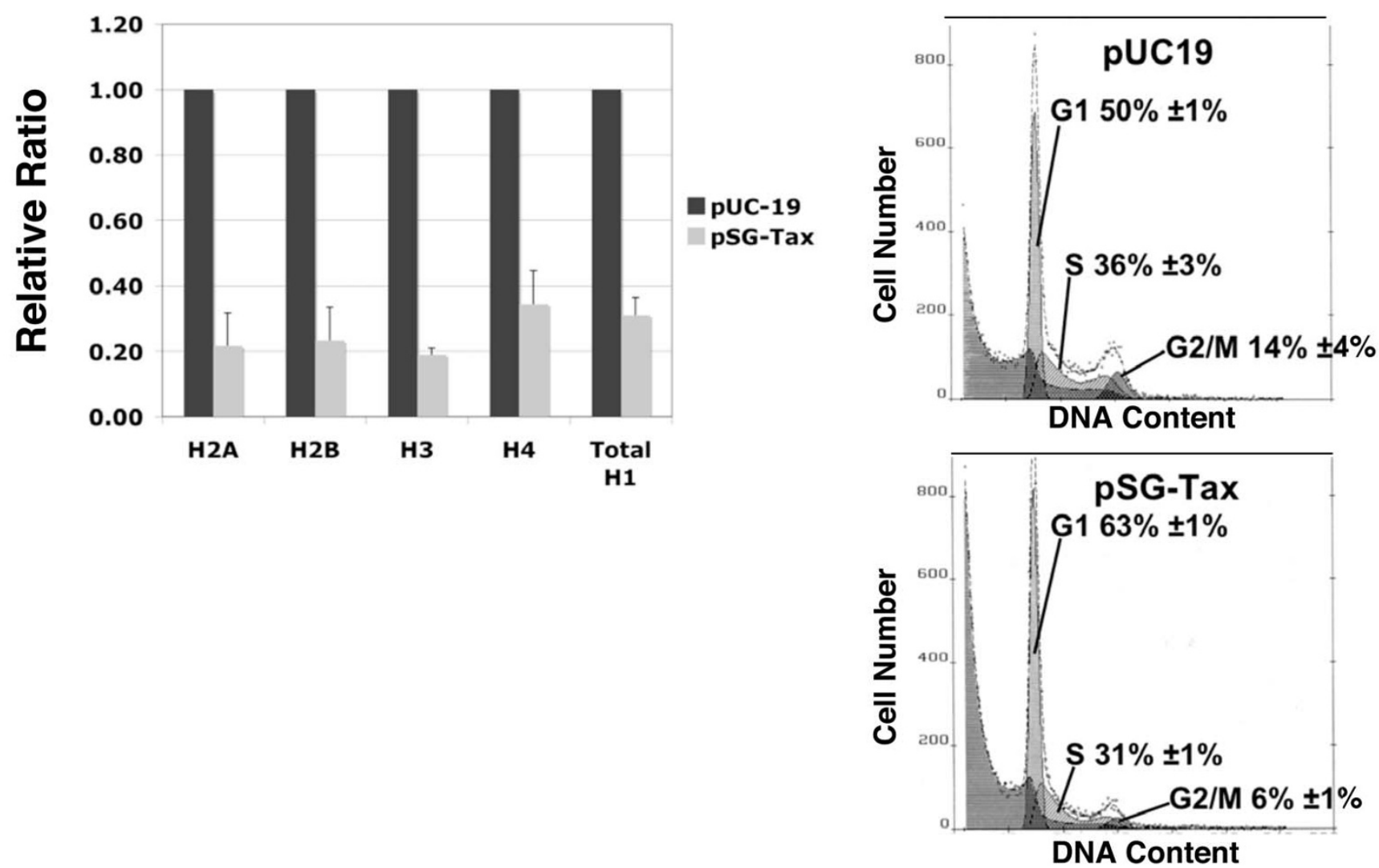

Figure 3

Tax expression is sufficient for reduction of replication-dependent histone transcript levels. (A) Histone transcript levels were measured in PSG-Tax transfected Jurkat cells and empty vector transfected Jurkat cells using reverse-transcription and real-time PCR. P-values associated with the measurement of histone transcripts in pUC-19 vs PSG-Tax transfected Jurkat cells were: $\mathrm{H} 2 \mathrm{~A}-3.7 \times 10^{-6}, \mathrm{H} 2 \mathrm{~B}-3.4 \times 10^{-5}, \mathrm{H} 3-5.6 \times 10^{-3}, \mathrm{H} 4-3.5 \times 10^{-2}$, average $\mathrm{HI}-\mathrm{I} . \mathrm{I} \times 10^{-2}$. (B) DNA content analysis reveals similar cell cycle distributions for PSG-Tax transfected and empty vector transfected Jurkat cells.

histone transcript levels observed in these Tax transfection studies.

\section{Discussion}

In this study we have shown that histone protein levels are reduced 20 to $40 \%$ in HTLV-1 infected T-cell lines as compared to uninfected T-cell lines and that this reduction correlates with decreased histone transcript levels. Additionally, we have shown that Tax alone is sufficient to decrease histone transcript levels. Replication-dependent histones are expressed only in S phase, so it was formally possible that the reduction in histone transcript levels observed after Tax expression in an uninfected T-cell line was the result of a significant decrease in the proportion of the cell population in $S$ phase. We have ruled out this possibility by analyzing cell cycle distributions of Tax expressing T-cells as compared to empty vector transfected T-cells (Figure 3B). Further, by measuring histone H3 levels and DNA content per cell simultaneously through flow cytometry we have demonstrated that the reduced histone levels observed in HTLV-1 infected T-cell lines do not occur through a reduction in the amount of genomic DNA in these cells. Rather, our results indicate that Tax deregulates histone production and this occurs, at least in part, through a decrease in histone gene transcripts resulting in reduced histone proteins assembled into nucleosomes on the genomic DNA. Furthermore, our data indicate that HTLV-1 infection can uncouple replication-dependent histone gene expression from DNA synthesis. It is important to point out that we cannot exclude cooperative 
effects from one or more of the other accessory HTLV-1 proteins in either the reduction of histone levels or the uncoupling of histone expression from DNA replication. However, Tax is sufficient to reduce histone mRNAs.

\section{Replication-dependent histone genes}

In normal somatic cells, expression of the majority of histone genes is tightly coupled to the rate of DNA replication during $S$ phase of the cell cycle. Thus, they are termed replication-dependent histone genes. Under normal circumstances inhibition of histone synthesis results in DNA replication arrest. Conversely, blocking DNA replication results in a coordinate inhibition of histone expression [68]. The coordination of histone expression and DNA synthesis is critical in the maintenance of chromosomal integrity [69]. Histone chaperones and chromatin assembly factors normally cooperate in the deposition of histones onto nascent DNA as it emerges from the replication fork [70]. The down-regulation of histone gene expression in response to decreased rates of DNA synthesis prevents the accumulation of excess histones, which has been shown to be highly cytotoxic and to severely compromise the transmission of chromosomal information [71]. Since there is no significant pool of non-nucleosomal histones, chromatin assembly at the replication fork is dependent on de novo histone expression.

Mammalian cell division requires the synthesis of $10^{8}$ histone proteins during the brief $\mathrm{S}$ phase. In order to meet these demands, cells contain multiple copies of the replication-dependent histone genes. Genomic sequence analysis has revealed 59 replication-dependent core histone genes and 6 replication-dependent linker histone genes, clustered at 4 different chromosomal loci in human cells [72]. The expression of all the replication-dependent histone genes is coordinately regulated during $\mathrm{S}$ phase. This coordinate regulation is mediated through both transcriptional and post-transcriptional mechanisms. It is not known how each of these different transcriptional and post-transcriptional mechanisms of histone gene regulation are coupled to the rate of DNA synthesis in proliferating cells.

\section{Replication-dependent histone gene transcriptional regulation}

The rate of transcription of all the replication-dependent histone genes increases three- to five-fold as cells enter S phase. Studies have shown that proper cell cycle-dependent transcriptional regulation of each histone subtype involves unique cis-regulatory elements and unique transcription factors for each histone subtype. It is not known how these different DNA-binding transcription factors are coordinated to activate transcription of all the replicationdependent histone genes in response to cell cycle signaling $[73,74]$. Recently, non DNA-binding proteins have been identified that may be involved in coordinating histone gene transcription. Hir1p and Hir2p are cell cycle regulators thought to be responsible for transcriptional co-repression of histone gene expression in Saccharomyces cerevisiae [75]. HIRA is the mammalian homolog of these yeast proteins and may regulate histone gene expression in mammalian cells. HIRA has been shown to display histone chaperone function independent of DNA synthesis [76]. It has also been shown to be phosphorylated by cyclin $\mathrm{E} / \mathrm{cdk} 2$ during $\mathrm{S}$ phase and is thought to be inhibited by this phosphorylation. The ectopic expression of HIRA is known to result in $S$ phase arrest and reduced histone transcript levels, suggesting a negative function for HIRA in replication-dependent histone gene expression outside of S phase [77].

NPAT is another mammalian protein thought to function in the coordinate expression of replication-dependent histone genes $[78,79]$. NPAT has also been shown to be an in vivo substrate of cyclin E/cdk2. Phosphorylation of NPAT correlates with the colocalization of NPAT to histone processing bodies. Inhibition of NPAT gene expression impedes cell cycle progression and decreases histone gene expression in mammalian cells [80]. Thus, NPAT is thought to participate in the up-regulation of replicationdependent histone gene expression during $S$ phase.

\section{Replication-dependent histone gene post-transcriptional regulation}

Post-transcriptional mechanisms of histone gene expression are responsible for an additional eight- to ten-fold increase in mRNA levels as cells enter $S$ phase $[81,82]$. The replication-dependent histones do not contain introns and are not polyadenylated. Instead, they all contain a very similar 3' stem-loop structure bound by a conserved protein in mammals, stem-loop binding protein (SLBP) $[83,84]$. SLBP mediates the only RNA processing event required for production of mature histone mRNAs, a 3'endonucleolytic cleavage [85]. In addition, SLBP binding regulates the half-life and translational efficiency of histone mRNAs [86-88].

\section{Potential mechanisms of Tax deregulation of histone expression}

As the promoters for the genes encoding the four replication-dependent histones have been shown to utilize unique cis-acting elements bound by different sequencespecific trans-acting factors during S-phase induced expression, Tax mediated repression of histone expression is likely to occur through an effect on one or more of the coordinating regulators of histone expression, HIRA, NPAT, or SLBP. The difference in reduction of histone protein levels (20 to $40 \%$ ) and histone transcript levels (50 to $80 \%$ ) suggests some compensation may occur through increased mRNA stability, translation efficiency or protein 
stability. In addition, results from this study suggest that HTLV-1 infection is able to uncouple the interdependence of histone gene expression and DNA synthesis. There is little known about the mechanism coupling histone synthesis and DNA replication. One candidate for this function is the histone chaperone Asf1 (Asf1a and Asf1b in mammalian cells), which has been shown to regulate histone levels during replicational stress [89]. Tax may provide a useful probe to investigate this coupling mechanism, as well as the mechanism of coordinate histone gene regulation in general.

\section{Potential effects of histone level reduction}

We find HTLV-1 infected cells with $~ 30 \%$ reductions in histone levels form apparently normal metaphase chromosomes, at least at the resolution of light microscopy (not shown). This indicates the reduction has more subtle effects. At the same time, we find that lower histone levels are not compensated for by merely increasing the nucleosomal repeat length to evenly distribute the remaining nucleosomes (not shown). Thus, one must assume there is a corresponding increase in non-nucleosomal DNA.

Chromatin structure plays a central role in the regulation of all DNA metabolic processes including transcription, replication, repair and recombination [61]. Post-translational modifications on the histone tails and histone variants are thought to be critical in the determination of cellular identity $[90,91]$. As every cell in a multi-cellular organism contains the same genomic information, cell differentiation and specialization require that distinct transcriptional programs are established and maintained $[92,93]$. Post-translational modifications on the histone tails are thought to impart cellular memory through epigenetic control of the genome [93]. Thus, every unique cell type is thought to exhibit a unique set of chromosome "marks", governing the genome-wide transcriptome and ultimately cellular identity. We suggest that a reduction of histone levels in HTLV-1 infected T-cells will result in loss of epigenetic information and may contribute to Tax deregulation of cellular gene expression leading to cancer.

We expect reduced histone levels to have similar effects as those observed with loss of imprinting (LOI) through DNA hypomethylation. These effects include aberrant chromosome rearrangements, deregulation of cellular gene expression and activation of latent viral genomes [94-100]. Reduction of histone levels could provide a means for HTLV-1 transcriptional reactivation after methylation of the 5' LTR in cultured ATLL cells [101].

Defects in chromatin assembly have been shown to impair all known pathways of double-strand break repair and activate $S$ phase arrest [102,103]. Furthermore, partial depletion of histone $\mathrm{H} 4$ has been shown to increase homologous recombination-mediated genetic instability [104].

Chromatin structure, nucleosome remodeling and the epigenetic information encoded on the histone tails are known to participate in double-strand DNA break repair [105-108]. Defects in nucleosome assembly have been shown to interfere with the repair of double-strand DNA breaks [102]. We suggest that a Tax-mediated decrease in histone levels will result in an increase in the incidence of double-strand DNA breaks. The ability of Tax to increase the frequency of double-strand DNA break formation is consistent with its ability to increase the propensity for micronuclei formation $[55,56]$. Double-strand DNA breaks are potent inducers of genome instability as they are repaired by the error-prone process of non-homologous end joining, when a sister chromatid is not available for more efficient recombination-mediated repair [109]. Decreased histone levels may represent a previously unknown means for Tax induction of DNA damage.

\section{Conclusion}

While the transforming capability of Tax has been demonstrated, the mechanisms of transformation by Tax are not completely understood. We suggest Tax repression of replication-dependent histone gene expression will result in reactivation of viral gene expression, deregulation of cellular gene expression and genomic instability. All of these effects may contribute to the development of adult T-cell leukemia/lymphoma. To our knowledge, this is the first example of a reduction of histone levels correlating with viral infection and cancer development.

\section{Methods \\ Cell lines and cell culture}

(C81, CEM, HuT102, Jurkat, Molt-4, and SLB-1) T-cell lines were cultured in Iscove's Modified Dulbecco's Media (IMDM; Sigma-Aldrich) supplemented with 10\% fetal bovine serum, 50,000 units/liter each streptomycin/penicillin and $2 \mathrm{mM}$ L-glutamine. All T-cell lines were cultured at $37^{\circ} \mathrm{C}$ in the presence of $5 \% \mathrm{CO}_{2}$.

\section{RNA extraction and CDNA synthesis}

RNA was extracted from asynchronous cells $\left(10^{7}\right)$ using Trizol (Invitrogen) in accordance with the manufacturer's protocol. In order to reduce genomic contamination, RNA samples were treated with 20 units of RNase-free DNase I (Roche) at room temperature for 30 minutes before heat inactivating the DNase I at $65^{\circ} \mathrm{C}$ for 10 minutes. cDNA was synthesized with the iScript cDNA synthesis kit (BioRad) according to manufacturer's protocol using a programmable thermal cycler. 


\section{Real-time PCR}

Relative real-time PCR was performed using iQ SYBR Green Supermix (Bio-Rad) on an iCycler (Bio-Rad) and data expressed according to the Michael Pfaffl method, using EF1 $\alpha$ as an internal control for normalization [110]. A five-point standard curve was constructed by serial diluting target DNA to evaluate PCR efficiency for every primer pair in every experiment. Reactions were performed in triplicate for every experiment. Real-time PCR amplicons were electrophoresed on 1.5\% agarose gels to verify the specificity of each primer pair and melt curves were analyzed for every experiment to ensure that amplification products were primer pair specific. The following primer sequences were used for real-time PCR:

H2A Fwd AGCTCAACAAGCTTCTGGGCAA;

H2A Rev TTGTGGTGGCTCTCGGTCTTCTT;

H2B Fwd TGCGCCCAAGAAGGGTTCTAAA;

H2B Rev ACGAAGGAGTTCATGATGCCCA;

H3 Fwd TGCTCATCCGCAAACTGCCATT; H3 Rev AGTGACACGCTTGGCGTGAATA; H4 Fwd ACCGTAAAGTAC TGCGCGACAA; H4 Rev TTCTCCAGGAACACCTTCAGC A; H1S-1 Fwd CCTGTAAAGAAGAAGGCGGCCAAA;

H1S-1 Rev CAGAGAAACTCCGCTACGCTCTTT;

H1S-2 Fwd CCCAGTATCTGAGCTTATCACCAAGG;

H1S-2 Rev TTTCTTAAGCGCGGCCAGAGAAAC;

H1S-3 Fwd CCCGGCTAAGAAGAAGGCAACTAA;

H1S-3 Rev GAAAGGCCATTGCGCTCCTTAGAA;

H1S-4 Fwd CCGGTGTCCGAGCTCATTACTAAA;

H1S-4 Rev GCTTTCTTGAGAGCGGCCAAAGAT;

EF1 $\alpha$ Fwd GCCTCTCCAGGATGTCTACAAA;

EF1 $\alpha$ Rev GTTTGAGAACACCAGTCTCCACTC;

Tax Fwd TTCTACCCGAAGACTGTTTGCCCA;

Tax Rev TGTCCAAATAAGGCCTGGAGTGGT.

Histone content relative to DNA content determination by flow cytometry

Asynchronous cells $\left(5 \times 10^{6}\right)$ from log phase culture were pelleted and suspended in ice-cold phosphate buffered saline (PBS). Cell suspensions were transferred to ice-cold
1\% formaldehyde (methanol-free) in PBS and chilled on ice for 15 minutes to fix cells. Cells were washed with icecold PBS and transferred to ice-cold 70\% ethanol and let stand at $-20^{\circ} \mathrm{C}$ for 2 hours to permeablize cells. Cells were washed with PBS and incubated in 1\% BSA-PBS containing $5 \mu \mathrm{g}$ primary antibody (ab1791 rabbit polyclonal to Histone H3, AbCam or mouse monoclonal antibody directed against histone H1 product \# V7013, Biomeda), overnight at $4{ }^{\circ} \mathrm{C}$ while rotating. Cells were then washed with $1 \%$ BSA-PBS and incubated in a $1 \%$ BSA-PBS solution containing $5 \mu \mathrm{g}$ of Alexa Fluor 488 goat anti-rabbit second antibody (product \# A11008, Molecular Probes) for Histone $\mathrm{H} 3$ analysis or Alexa Fluor 488 goat antimouse second antibody (product \# A11029, Molecular Probess) for Histone $\mathrm{H} 1$ analysis, for 1 hour at room temperature. Cells were washed with 1\% BSA-PBS and incubated in PBS containing $25 \mathrm{ug} / \mathrm{mL}$ propidium iodide (Sigma) and $40 \mathrm{Kunitz} \mathrm{U} / \mathrm{mL}$ RNase A (Sigma, certified DNase-free) for 30 minutes at room temperature. Cells were analyzed on a MoFlo (Dako Cytomation) flow cytometer/cell sorter with laser excitation at $488 \mathrm{~nm}$ with $110 \mathrm{~mW}$. Data was interpreted using Summit software, version 4.0 (Dako Cytomation).

\section{Northern blots}

Total RNA (10 $\mu \mathrm{g}$ ) was resolved on $1 \%$ agarose/6.6\% formaldehyde gels. Samples were transferred to a nylon membrane and probed with histone and EF1 $\alpha$ probes simultaneously. PhosphorImager screens were scanned on a STORM (Molecular Probes). Histone signals were quantified with ImageQuant software version 5.1 (Molecular Dynamics) and normalized to EF1 $\alpha$ signals. Probes were generated using a random primed DNA labeling kit (Roche). The DNA templates used for the generation of 32P-radiolabeled probes for histone and EF1 $\alpha$ transcripts were prepared by PCR from Jurkat genomic DNA using the following primers:

H1 Fwd AAGGAGCGCAATGGCCTTTCTTTG;

H1 Rev GCCTTCTTGGCCTTTGCAGCTTTA;

H2A Fwd TTCAGTTTCCCGTAGGCCGAGT, H2A Rev GA AGCTTGTTGAGCTCCTCATCGT;

H2B Fwd AAGAAGGATGGCAAGAAGCGCAAG;

H2B Rev ACTTGGAGCTGGTGTACTTGGTGA;

H3 Fwd ATCGCTATCGGCCTGGTACAGT;

H3 Rev AGCTGGATGTCCTTGGGCATGATA;

H4 Fwd ATGTCAGGACGCGGCAAAGGAGGTAA; 


\section{H4 Rev GATCACGTTCTCCAGGAACACCTTCA;}

\section{EF1 $\alpha$ Fwd TCATTGGACACGTAGATTCGGGCA;}

\section{EF1 $\alpha$ Rev TTCACACCCAGTGTGTAAGCCAGA.}

The DNA template used for the generation of 32P-radiolabeled probes for Tax transcripts was prepared by PCR from pSG-Tax plasmid DNA using the following primers:

\section{Tax Fwd TTCCCAGGGTTTGGACAGAGTCTT;}

\section{Tax Rev GCGTGCCATCGGTAAATGTCCAAA}

\section{Co-transfection and magnetic selection of transfectants} Jurkat cells were co-transfected with pSG-Tax/pMACs $\mathrm{K}^{\mathrm{k}}$ or pUC-19/pMACs $\mathrm{K}^{\mathrm{k}}$ at $20 \mathrm{ug}$ total DNA (3.5 molar excess of pMACs $\mathrm{K}^{\mathrm{k}}$ ) per $10^{7}$ cells by electroporation in 0.4 cm cuvettes using Genepulse (Bio-Rad). Transfected cells were enriched 24 hours following electroporation using the pMACS Kk magnetic selection system (Miltenyi Biotec) according to the manufacturer's protocol. Enriched cell populations were cultured for an additional 24 hours prior to harvesting cells for RNA extraction and DNA content analysis.

\section{DNA content analysis}

Asynchronous cells $\left(10^{6}\right)$ from log phase culture were fixed with $70 \%$ ethanol and low molecular weight DNA was extracted with a $4 \mathrm{mM}$ sodium citrate/192 mM sodium phosphate wash. Fixed cells were stained with 50 $\mathrm{ug} / \mathrm{mL}$ propidium iodide in PBS containing $730 \mathrm{Kunitz} \mathrm{U} /$ mL RNase A for 20 minutes at room temperature. Data was collected on an EPICS flow cytometer (Beckman Coulter) and cell cycle distributions were calculated using Multicycle (Phoenix Flow Systems).

\section{Authors' contributions}

JMB carried out the flow cytometry measurement of protein and DNA content, the reverse transcriptase/real-time PCR and Northern blot analyses of transcript levels in uninfected cells, HTLV-1 infected cells, mock transfected cells and Tax expression vector transfected cells. PJL conceived the study and participated in the design of the experiments and the interpretation of the results. All authors read and approved the final manuscript.

\section{Acknowledgements}

This study was supported by grants from the Colorado Cancer League and the American Heart Association awarded to PJL.

We thank Nicholas Polakowski and Isabelle Lemasson for technical assistance, insightful discussion and critical reading of the manuscript. Thanks to Timothy Geiger for suggesting the flow cytometry experiments. We thank Leslie Armstrong for help with collecting flow cytometry data. We thank Michael Fox for help with reviewing the flow cytometry data. We thank
Warner Greene for providing the PSG-Tax expression vector. Thanks to Bill Marzluff, Jiyong Zhao and members of the BMB and MIP Departments at CSU for many useful discussions of our results.

\section{References}

I. Poiesz BJ, Ruscetti FW, Gazdar AF, Bunn PA, Minna JD, Gallo RC: Detection and isolation of type $C$ retrovirus particles from fresh and cultured lymphocytes of a patient with cutaneous T-cell lymphoma. Proc Natl Acad Sci $U$ S A 1980, 77(12):7415-7419.

2. Yoshida M, Miyoshi I, Hinuma Y: Isolation and characterization of retrovirus from cell lines of human adult $\mathrm{T}$-cell leukemia and its implication in the disease. Proc Natl Acad Sci U S A 1982 , 79(6):203।-2035.

3. Miyoshi I, Kubonishi I, Yoshimoto S, Akagi T, Ohtsuki Y, Shiraishi Y, Nagata $K$, Hinuma $Y$ : Type $C$ virus particles in a cord $\mathbf{T}$-cell line derived by co-cultivating normal human cord leukocytes and human leukaemic T cells. Nature I98I, 294(5843):770-77I.

4. Hinuma $Y$, Nagata K, Hanaoka M, Nakai M, Matsumoto T, Kinoshita KI, Shirakawa S, Miyoshi I: Adult T-cell leukemia: antigen in an ATL cell line and detection of antibodies to the antigen in human sera. Proc Natl Acad Sci U S A 198I, 78( I 0):6476-6480.

5. Uchiyama T, Yodoi J, Sagawa K, Takatsuki K, Uchino H: Adult T-cell leukemia: clinical and hematologic features of 16 cases. Blood 1977, 50(3):481-492.

6. Grassmann R, Dengler C, Muller-Fleckenstein I, Fleckenstein B, McGuire K, Dokhelar MC, Sodroski JG, Haseltine WA: Transformation to continuous growth of primary human $T$ lymphocytes by human $\mathbf{T}$-cell leukemia virus type I X-region genes transduced by a Herpesvirus saimiri vector. Proc Natl Acad Sci U S A 1989, 86(9):335I-3355.

7. Takatsuki K: Adult T-cell leukemia. Intern Med 1995, 34( I 0):947-952.

8. Gessain A, Barin F, Vernant JC, Gout O, Maurs L, Calender A, de The G: Antibodies to human T-lymphotropic virus type-I in patients with tropical spastic paraparesis. Lancet 1985, 2(8452):407-4I0.

9. Osame M, Nakagawa M, Umehara F, ljichi S, Moritoyo T, Higuchi I, Usuku K, Arimura K, Izumo S: Recent studies on the epidemiology, clinical features and pathogenic mechanisms of HTLV-I associated myelopathy (HAM/TSP) and other diseases associated to HTLV. J Neurovirol I997, 3 Suppl I:S50-I.

10. Silva MT, Harab RC, Leite AC, Schor D, Araujo A, Andrada-Serpa MJ: Human T lymphotropic virus type I (HTLV-I) proviral load in asymptomatic carriers, HTLV-I-associated myelopathy/ tropical spastic paraparesis, and other neurological abnormalities associated with HTLV-I infection. Clin Infect Dis 2007, 44(5):689-692.

II. Seiki M, Hattori S, Hirayama Y, Yoshida M: Human adult T-cell leukemia virus: complete nucleotide sequence of the provirus genome integrated in leukemia cell DNA. Proc Natl Acad Sci U S A 1983, 80(12):3618-3622.

12. Seiki M, Eddy R, Shows TB, Yoshida M: Nonspecific integration of the HTLV provirus genome into adult $\mathrm{T}$-cell leukaemia cells. Nature 1984, 309(5969):640-642.

13. Kiyokawa T, Seiki M, Imagawa K, Shimizu F, Yoshida M: Identification of a protein $(p 40 x)$ encoded by a unique sequence $p X$ of human T-cell leukemia virus type I. Gann 1984, 75(9):747-75I.

14. Hiraragi H, Kim SJ, Phipps AJ, Silic-Benussi M, Ciminale V, Ratner L, Green PL, Lairmore MD: Human T-lymphotropic virus type I mitochondrion-localizing protein pl3(II) is required for viral infectivity in vivo. J Virol 2006, 80(7):3469-3476.

15. Kiyokawa T, Seiki M, Iwashita S, Imagawa K, Shimizu F, Yoshida M: p27x-III and $p 2 I x-I I I$, proteins encoded by the $p X$ sequence of human T-cell leukemia virus type I. Proc Natl Acad Sci U S A 1985, 82(24):8359-8363.

16. Seiki M, Hikikoshi A, Taniguchi T, Yoshida M: Expression of the $\mathbf{p X}$ gene of HTLV-I: general splicing mechanism in the HTLV family. Science 1985, 228(4707): I532-I534.

17. Hidaka M, Inoue J, Yoshida M, Seiki M: Post-transcriptional regulator (rex) of HTLV-I initiates expression of viral structural proteins but suppresses expression of regulatory proteins. Embo J 1988, 7(2):519-523.

18. Seiki M, Inoue J, Hidaka M, Yoshida M: Two cis-acting elements responsible for posttranscriptional trans-regulation of gene 
expression of human T-cell leukemia virus type I. Proc Natl Acad Sci U S A 1988, 85(19):7|24-7|28.

19. Seiki M, Inoue J, Takeda T, Hikikoshi A, Sato M, Yoshida M: The p40x of human T-cell leukemia virus type $I$ is a trans-acting activator of viral gene transcription. Jpn J Cancer Res 1985, 76(I2): ||27-||3|.

20. Grossman WJ, Kimata JT, Wong FH, Zutter M, Ley TJ, Ratner L: Development of leukemia in mice transgenic for the tax gene of human T-cell leukemia virus type I. Proc Natl Acad Sci U S A 1995, 92(4): |057-|06|.

21. Pozzatti R, Vogel J, Jay G: The human T-lymphotropic virus type I tax gene can cooperate with the ras oncogene to induce neoplastic transformation of cells. Mol Cell Biol 1990, IO(I):4I3-4I7.

22. Smith MR, Greene WC: Type I human T cell leukemia virus tax protein transforms rat fibroblasts through the cyclic adenosine monophosphate response element binding protein/activating transcription factor pathway. J Clin Invest |99|, 88(3): $1038-1042$.

23. Tanaka A, Takahashi C, Yamaoka S, Nosaka T, Maki M, Hatanaka M Oncogenic transformation by the tax gene of human T-cell leukemia virus type I in vitro. Proc Natl Acad Sci U S A 1990, 87(3): $107 \mid-1075$

24. Grassmann R, Berchtold S, Radant I, Alt M, Fleckenstein B, Sodroski JG, Haseltine WA, Ramstedt U: Role of human T-cell leukemia virus type I $\mathbf{X}$ region proteins in immortalization of primary human lymphocytes in culture. J Virol 1992, 66(7):4570-4575

25. Jeang KT, Giam CZ, Majone F, Aboud M: Life, death, and tax: role of HTLV-I oncoprotein in genetic instability and cellular transformation. J Biol Chem 2004, 279(3I):31991-3 I994.

26. Gatza ML, Watt JC, Marriott S): Cellular transformation by the HTLV-I Tax protein, a jack-of-all-trades. Oncogene 2003 22(33):5|4|-5|49.

27. Yoshida M: Multiple viral strategies of HTLV-I for dysregulation of cell growth control. Annu Rev Immunol 200I, 19:475-496.

28. Marriott SJ, Semmes OJ: Impact of HTLV-I Tax on cell cycle progression and the cellular DNA damage repair response. Oncogene 2005, 24(39):5986-5995.

29. Igakura T, Stinchcombe JC, Goon PK, Taylor GP, Weber JN, Griffiths GM, Tanaka Y, Osame M, Bangham CR: Spread of HTLV-I between lymphocytes by virus-induced polarization of the cytoskeleton. Science 2003, 299(56/3): 17|3-17/6.

30. Fan N, Gavalchin J, Paul B, Wells KH, Lane MJ, Poiesz BJ: Infection of peripheral blood mononuclear cells and cell lines by cellfree human T-cell lymphoma/leukemia virus type I. J Clin Microbiol 1992, 30(4):905-910.

31. Derse D, Hill SA, Lloyd PA, Chung H, Morse BA: Examining human T-lymphotropic virus type I infection and replication by cellfree infection with recombinant virus vectors. J Virol 200I, 75(I 8):846|-8468.

32. Nicot C, Harrod RL, Ciminale V, Franchini G: Human T-cell leukemia/lymphoma virus type I nonstructural genes and their functions. Oncogene 2005, 24(39):6026-6034.

33. Collins ND, Newbound GC, Albrecht B, Beard JL, Ratner L, Lairmore MD: Selective ablation of human T-cell lymphotropic virus type I pl2I reduces viral infectivity in vivo. Blood 1998, 9 I(I 2):470I-4707.

34. Silverman LR, Phipps AJ, Montgomery A, Ratner L, Lairmore MD: Human T-cell lymphotropic virus type I open reading frame II-encoded $\mathrm{p} 30 \mathrm{II}$ is required for in vivo replication: evidence of in vivo reversion. J Virol 2004, 78(8):3837-3845.

35. Younis I, Yamamoto B, Phipps A, Green PL: Human T-cell leukemia virus type $I$ expressing nonoverlapping tax and rex genes replicates and immortalizes primary human $T$ lymphocytes but fails to replicate and persist in vivo. J Virol 2005 , 79(23): |4473- |448|

36. Ding W, Albrecht B, Luo R, Zhang W, Stanley JR, Newbound GC Lairmore MD: Endoplasmic reticulum and cis-Golgi localization of human T-lymphotropic virus type I p/2(I): association with calreticulin and calnexin. I Virol 200I, 75(16):7672-7682.

37. Johnson JM, Nicot C, Fullen J, Ciminale V, Casareto L, Mulloy JC, Jacobson S, Franchini G: Free major histocompatibility complex class I heavy chain is preferentially targeted for degradation by human T-cell leukemia/lymphotropic virus type I pI 2(I) protein. J Virol 200I, 75(I3):6086-6094.
38. Awasthi S, Sharma A, Wong K, Zhang J, Matlock EF, Rogers L, Motloch P, Takemoto S, Taguchi H, Cole MD, Luscher B, Dittrich O, Tagami H, Nakatani Y, McGee M, Girard AM, Gaughan L, Robson CN, Monnat RJ Jr., Harrod R: A human T-cell lymphotropic virus type I enhancer of Myc transforming potential stabilizes Myc-TIP60 transcriptional interactions. Mol Cell Biol 2005, 25(14):6178-6198

39. Nicot C, Dundr M, Johnson JM, Fullen JR, Alonzo N, Fukumoto R, Princler GL, Derse D, Misteli T, Franchini G: HTLV-I-encoded p30II is a post-transcriptional negative regulator of viral replication. Nat Med 2004, I 0(2):197-20I.

40. Zhang W, Nisbet JW, Bartoe JT, Ding W, Lairmore MD: Human Tlymphotropic virus type I p30(II) functions as a transcription factor and differentially modulates CREB-responsive promoters. J Virol 2000, 74(23): I I270- I I 277.

41. D'Agostino DM, Ranzato L, Arrigoni G, Cavallari I, Belleudi F, Torrisi MR, Silic-Benussi M, Ferro T, Petronilli V, Marin O, Chieco-Bianchi L, Bernardi $\mathrm{P}$, Ciminale V: Mitochondrial alterations induced by the pI 3 II protein of human T-cell leukemia virus type I. Critical role of arginine residues. I Biol Chem 2002, 277(37):34424-34433

42. Gaudray G, Gachon F, Basbous J, Biard-Piechaczyk M, Devaux C, Mesnard JM: The complementary strand of the human T-cell leukemia virus type I RNA genome encodes a bZIP transcription factor that down-regulates viral transcription. Virol 2002, 76(24): 128I3-12822

43. Larocca D, Chao LA, Seto MH, Brunck TK: Human T-cell leukemia virus minus strand transcription in infected T-cells. Biochem Biophys Res Commun 1989, 163(2): 1006-1013.

44. Lemasson I, Lewis MR, Polakowski N, Hivin P, Cavanagh MH, Thebault S, Barbeau B, Nyborg JK, Mesnard JM: Human T-cell leukemia virus type I (HTLV-I) bZIP protein interacts with the cellular transcription factor CREB to inhibit HTLV-I transcription. I Virol 2007, 8I(4): I543-I553.

45. Basbous J, Arpin C, Gaudray G, Piechaczyk M, Devaux C, Mesnard JM: The HBZ factor of human T-cell leukemia virus type I dimerizes with transcription factors JunB and c-Jun and modulates their transcriptional activity. I Biol Chem 2003, 278(44):43620-43627.

46. Satou Y, Yasunaga J, Yoshida M, Matsuoka M: HTLV-I basic leucine zipper factor gene mRNA supports proliferation of adult $T$ cell leukemia cells. Proc Natl Acad Sci U S A 2006, I 03(3):720-725

47. Inoue J, Seiki M, Yoshida M: The second $\mathrm{pX}$ product $\mathrm{p} 27 \mathrm{chi}$-III of HTLV-I is required for gag gene expression. FEBS Lett 1986 , 209(2): $187-190$.

48. Inoue J, Yoshida M, Seiki M: Transcriptional (p40x) and posttranscriptional (p27x-III) regulators are required for the expression and replication of human T-cell leukemia virus type I genes. Proc Natl Acad Sci U S A 1987, 84(II):3653-3657.

49. Black AC, Chen IS, Arrigo S, Ruland CT, Allogiamento T, Chin E, Rosenblatt JD: Regulation of HTLV-II gene expression by Rex involves positive and negative cis-acting elements in the 5'long terminal repeat. Virology I99 I, I 8 I (2):433-444.

50. Ye J, Silverman L, Lairmore MD, Green PL: HTLV-I Rex is required for viral spread and persistence in vivo but is dispensable for cellular immortalization in vitro. Blood 2003, I02(I 2):3963-3969.

5I. Tsukasaki K, Koeffler P, Tomonaga M: Human T-lymphotropic virus type I infection. Baillieres Best Pract Res Clin Haematol 2000, 13(2):23|-243.

52. Lengauer C, Kinzler KW, Vogelstein B: Genetic instabilities in human cancers. Nature 1998, 396(67 I 2):643-649.

53. Kamada N, Sakurai M, Miyamoto K, Sanada I, Sadamori N, Fukuhara S, Abe S, Shiraishi Y, Abe T, Kaneko Y, et al.: Chromosome abnormalities in adult T-cell leukemia/lymphoma: a karyotype review committee report. Cancer Res 1992, 52(6): I 48I- I 493.

54. Fujimoto $T$, Hata $T$, Itoyama $T$, Nakamura $H$, Tsukasaki $K$, Yamada $Y$ Ikeda S, Sadamori N, Tomonaga M: High rate of chromosomal abnormalities in HTLV-I-infected T-cell colonies derived from prodromal phase of adult T-cell leukemia: a study of IL2-stimulated colony formation in methylcellulose. Cancer Genet Cytogenet 1999, 109( I): I-13.

55. Semmes OJ, Majone F, Cantemir C, Turchetto L, Hjelle B, Jeang KT: HTLV-I and HTLV-II Tax: differences in induction of micronuclei in cells and transcriptional activation of viral LTRs. Virology 1996, 217(1):373-379. 
56. Majone F, Semmes OJ, Jeang KT: Induction of micronuclei by HTLV-I Tax: a cellular assay for function. Virology 1993 I 93( I):456-459.

57. Lemoine FJ, Marriott SJ: Genomic instability driven by the human T-cell leukemia virus type I (HTLV-I) oncoprotein, Tax. Oncogene 2002, 2 I (47):7230-7234.

58. Liang MH, Geisbert T, Yao Y, Hinrichs SH, Giam CZ: Human Tlymphotropic virus type I oncoprotein tax promotes $S$ phase entry but blocks mitosis. J Virol 2002, 76(8):4022-4033

59. Bennett JM, Catovsky D, Daniel MT, Flandrin G, Galton DA, Gralnick HR, Sultan C: Proposals for the classification of chronic (mature) B and T Iymphoid leukaemias. French-AmericanBritish (FAB) Cooperative Group. J Clin Pathol 1989, 42(6):567-584.

60. Majone $\mathrm{F}$, Jeang KT: Clastogenic effect of the human T-cell leukemia virus type I Tax oncoprotein correlates with unstabilized DNA breaks. J Biol Chem 2000, 275(42):32906-329I0.

61. Luger K, Hansen JC: Nucleosome and chromatin fiber dynamics. Curr Opin Struct Biol 2005, I 5(2): 188-196.

62. Tsukasaki K, Tanosaki S, DeVos S, Hofmann WK, Wachsman W Gombart AF, Krebs J, Jauch A, Bartram CR, Nagai K, Tomonaga M, Said JW, Koeffler HP: Identifying progression-associated genes in adult $\mathrm{T}$-cell leukemia/lymphoma by using oligonucleotide microarrays. Int J Cancer 2004, I09(6):875-88I.

63. Pise-Masison CA, Radonovich M, Mahieux R, Chatterjee $P$, Whiteford C, Duvall J, Guillerm C, Gessain A, Brady JN: Transcription profile of cells infected with human T-cell leukemia virus type I compared with activated lymphocytes. Cancer Res 2002 62(I 2):3562-357I.

64. $\mathrm{Ng} P W$, Iha $\mathrm{H}$, Iwanaga $\mathrm{Y}$, Bittner $\mathrm{M}$, Chen $\mathrm{Y}$, Jiang $\mathrm{Y}$, Gooden $\mathrm{G}$, Trent JM, Meltzer P, Jeang KT, Zeichner SL: Genome-wide expression changes induced by HTLV-I Tax: evidence for MLK-3 mixed lineage kinase involvement in Tax-mediated NF-kappaB activation. Oncogene 200I, 20(33):4484-4496.

65. Koga $H$, Imada $K$, Ueda $M$, Hishizawa $M$, Uchiyama T: Identification of differentially expressed molecules in adult T-cell leukemia cells proliferating in vivo. Cancer Sci 2004, 95(5):4 I I-4I7.

66. Oliver D, Granner D, Chalkley R: Identification of a distinction between cytoplasmic histone synthesis and subsequent histone deposition within the nucleus. Biochemistry 1974 I 3(4):746-749.

67. Bonner WM, Wu RS, Panusz HT, Muneses C: Kinetics of accumulation and depletion of soluble newly synthesized histone in the reciprocal regulation of histone and DNA synthesis. Biochemistry 1988, 27( I 7):6542-6550.

68. Zhao J: Coordination of DNA synthesis and histone gene expression during normal cell cycle progression and after DNA damage. Cell Cycle 2004, 3(6):695-697.

69. Gunjan A, Paik J, Verreault A: Regulation of histone synthesis and nucleosome assembly. Biochimie 2005, 87(7):625-635.

70. Sogo JM, Stahl H, Koller T, Knippers R: Structure of replicating simian virus $\mathbf{4 0}$ minichromosomes. The replication fork, core histone segregation and terminal structures. I Mol Biol I 986, I 89(I): |89-204.

71. Gunjan A, Verreault A: A Rad53 kinase-dependent surveillance mechanism that regulates histone protein levels in S. cerevisiae. Cell 2003, I I 5(5):537-549.

72. Marzluff WF, Gongidi P, Woods KR, Jin J, Maltais LJ: The human and mouse replication-dependent histone genes. Genomics 2002 80(5):487-498.

73. Marzluff WF, Duronio RJ: Histone mRNA expression: multiple levels of cell cycle regulation and important developmental consequences. Curr Opin Cell Biol 2002, I 4(6):692-699.

74. Osley MA: The regulation of histone synthesis in the cell cycle. Annu Rev Biochem 1991, 60:827-86।.

75. Spector MS, Raff A, DeSilva H, Lee K, Osley MA: Hir Ip and Hir2p function as transcriptional corepressors to regulate histone gene transcription in the Saccharomyces cerevisiae cell cycle. Mol Cell Biol 1997, I 7(2):545-552

76. Ray-Gallet D, Quivy JP, Scamps C, Martini EM, Lipinski M, Almouzn G: HIRA is critical for a nucleosome assembly pathway independent of DNA synthesis. Mol Cell 2002, 9(5): I09|-II00.

77. Hall C, Nelson DM, Ye X, Baker K, DeCaprio JA, Seeholzer S, Lipinski $M$, Adams PD: HIRA, the human homologue of yeast Hirlp and Hir 2 p, is a novel cyclin-cdk2 substrate whose expression blocks S-phase progression. Mol Cell Biol 200 I, 2 I (5): I 854-I865.
78. Zhao J, Kennedy BK, Lawrence BD, Barbie DA, Matera AG, Fletcher JA, Harlow E: NPAT links cyclin E-Cdk2 to the regulation of replication-dependent histone gene transcription. Genes Dev 2000, I 4( I 8):2283-2297.

79. Ma T, Van Tine BA, Wei Y, Garrett MD, Nelson D, Adams PD, Wang J, Qin J, Chow LT, Harper JW: Cell cycle-regulated phosphorylation of p220(NPAT) by cyclin E/Cdk2 in Cajal bodies promotes histone gene transcription. Genes Dev 2000, I 4( I 8):2298-23 I 3

80. Gao G, Bracken AP, Burkard K, Pasini D, Classon M, Attwooll C Sagara $M$, Imai T, Helin $K$, Zhao J: NPAT expression is regulated by $E 2 F$ and is essential for cell cycle progression. Mol Cell Biol 2003, 23(8):282I-2833.

8I. Heintz N, Sive HL, Roeder RG: Regulation of human histone gene expression: kinetics of accumulation and changes in the rate of synthesis and in the half-lives of individual histone mRNAs during the HeLa cell cycle. Mol Cell Biol 1983, 3(4):539-550.

82. DeLisle AJ, Graves RA, Marzluff WF, Johnson LF: Regulation of histone mRNA production and stability in serum-stimulated mouse 3 T6 fibroblasts. Mol Cell Biol I983, 3(I I): I920-1929.

83. Dominski Z, Zheng LX, Sanchez R, Marzluff WF: Stem-loop binding protein facilitates 3 '-end formation by stabilizing U7 snRNP binding to histone pre-mRNA. Mol Cell Biol 1999 I 9(5):356I-3570.

84. Birchmeier C, Folk W, Birnstiel ML: The terminal RNA stemloop structure and $\mathbf{8 0}$ bp of spacer DNA are required for the formation of 3' termini of sea urchin H2A mRNA. Cell 1983 , 35(2 Pt I):433-440.

85. Wang ZF, Whitfield ML, Ingledue TC 3rd, Dominski Z, Marzluff WF: The protein that binds the 3' end of histone mRNA: a novel RNA-binding protein required for histone pre-mRNA processing. Genes Dev 1996, I0(23):3028-3040.

86. Whitfield ML, Zheng LX, Baldwin A Ohta T, Hurt MM, Marzluff WF: Stem-loop binding protein, the protein that binds the 3 ' end of histone mRNA, is cell cycle regulated by both translational and posttranslational mechanisms. Mol Cell Biol 2000 20(1 2):4188-4198.

87. Sanchez R, Marzluff WF: The stem-loop binding protein is required for efficient translation of histone mRNA in vivo and in vitro. Mol Cell Biol 2002, 22(20):7093-7I04.

88. Ling J, Morley SJ, Pain VM, Marzluff WF, Gallie DR: The histone 3'terminal stem-loop-binding protein enhances translation through a functional and physical interaction with eukaryotic initiation factor 4G (elF4G) and elF3. Mol Cell Biol 2002, 22(22):7853-7867

89. Groth A, Ray-Gallet D, Quivy JP, Lukas J, Bartek J, Almouzni G: Human AsfI regulates the flow of $S$ phase histones during replicational stress. Mol Cell 2005, I 7(2):30 I-3 I I.

90. Feinberg AP, Tycko B: The history of cancer epigenetics. Nat Rev Cancer 2004, 4(2): | 43-153.

91. Turner BM: Cellular memory and the histone code. Cell 2002, I I I (3):285-29I.

92. Cavalli G: Chromatin and epigenetics in development: blending cellular memory with cell fate plasticity. Development 2006 I 33( I I):2089-2094.

93. Cavalli G: Chromatin as a eukaryotic template of genetic information. Curr Opin Cell Biol 2002, I4(3):269-278.

94. Qu GZ, Grundy PE, Narayan A, Ehrlich M: Frequent hypomethylation in Wilms tumors of pericentromeric DNA in chromosomes I and I6. Cancer Genet Cytogenet 1999, I09(I):34-39.

95. Nakayama M, Wada M, Harada T, Nagayama J, Kusaba H, Ohshima K Kozuru M, Komatsu H, Ueda R, Kuwano M: Hypomethylation status of $\mathrm{CpG}$ sites at the promoter region and overexpression of the human MDRI gene in acute myeloid leukemias. Blood I998, 92( I I):4296-4307.

96. Suter CM, Martin DI, Ward RL: Hypomethylation of LI retrotransposons in colorectal cancer and adjacent normal tissue. Int J Colorectal Dis 2004, I 9(2):95-I0I.

97. Badal V, Chuang LS, Tan EH, Badal S, Villa LL, Wheeler CM, Li BF, Bernard HU: CpG methylation of human papillomavirus type 16 DNA in cervical cancer cell lines and in clinical specimens: genomic hypomethylation correlates with carcinogenic progression. J Virol 2003, 77( I I ):6227-6234 
98. Eden A, Gaudet F, Waghmare A, Jaenisch R: Chromosomal instability and tumors promoted by DNA hypomethylation. Science 2003, 300(56 I 8):455.

99. Feinberg AP, Ohlsson R, Henikoff S: The epigenetic progenitor origin of human cancer. Nat Rev Genet 2006, 7(I):2 I-33.

100. Ting AH, McGarvey KM, Baylin SB: The cancer epigenome--components and functional correlates. Genes Dev 2006, 20(23):32|5-323|.

I0I. Taniguchi Y, Nosaka K, Yasunaga J, Maeda M, Mueller N, Okayama A, Matsuoka M: Silencing of human T-cell leukemia virus type I gene transcription by epigenetic mechanisms. Retrovirology 2005, 2:64.

102. Lewis LK, Karthikeyan G, Cassiano J, Resnick MA: Reduction of nucleosome assembly during new DNA synthesis impairs both major pathways of double-strand break repair. Nucleic Acids Res 2005, 33( I 5):4928-4939.

103. Ye X, Franco AA, Santos H, Nelson DM, Kaufman PD, Adams PD: Defective $S$ phase chromatin assembly causes DNA damage, activation of the $S$ phase checkpoint, and $S$ phase arrest. Mol Cell 2003, I I(2):34I-35I.

104. Prado F, Aguilera A: Partial depletion of histone $\mathbf{H 4}$ increases homologous recombination-mediated genetic instability. Mol Cell Biol 2005, 25(4): I526-I536.

105. Osley MA, Tsukuda T, Nickoloff JA: ATP-dependent chromatin remodeling factors and DNA damage repair. Mutat Res 2007.

106. Karagiannis TC, El-Osta A: Epigenetic changes activate widespread signals in response to double-strand breaks. Cancer Biol Ther 2004, 3(7):617-623.

107. Bao Y, Shen X: Chromatin remodeling in DNA double-strand break repair. Curr Opin Genet Dev 2007.

108. Fillingham J, Keogh MC, Krogan NJ: GammaH2AX and its role in DNA double-strand break repair. Biochem Cell Biol 2006, 84(4):568-577.

109. Karagiannis TC, El-Osta A: Double-strand breaks: signaling pathways and repair mechanisms. Cell Mol Life Sci 2004, 6 I(17):2 I37-2|47.

I 10. Pfaffl MW: A new mathematical model for relative quantification in real-time RT-PCR. Nucleic Acids Res 200I, 29(9):e45.
Publish with Bio Med Central and every scientist can read your work free of charge

"BioMed Central will be the most significant development for disseminating the results of biomedical research in our lifetime. "

Sir Paul Nurse, Cancer Research UK

Your research papers will be:

- available free of charge to the entire biomedical community

- peer reviewed and published immediately upon acceptance

- cited in PubMed and archived on PubMed Central

- yours - you keep the copyright

Submit your manuscript here:

http://www.biomedcentral.com/info/publishing_adv.asp
BioMedcentral 